\title{
Environmental Assessment of Water Quality in the Qarraoun Lake: The Investigation of Physico- Chemistry and Microbial Properties
}

\author{
Chaden Haydar \\ Nada Nehme \\ Rime kamar \\ Faculty of Agricultural Engineering and Veterinary Medicine, \\ Lebanese University Dekwaneh, Beirut, Lebanon
}

Doi: 10.19044/esj.2018.c5p14 ～URL:http://dx.doi.org/10.19044/esj.2018.c5p14

\begin{abstract}
The Qarraoun Lake is the largest artificial reservoir in Lebanon, which is located along the Litani River in the Bekaa plain. It represents the connecting point between the Upper and Lower Litani River Basins. Water collected in the lake is used for multipurpose, and mainly for irrigation, fisheries, power generation, and domestic water use. Recently, the Lake has been witnessing severe deterioration in water quality due to uncontrolled liquid and soil waste disposal in the Upper River Basin. As a result, the pollutants accumulate into the Lake water. Apart from laboratory analysis for water quality, the pollution is obvious through direct observations, smells, and water color and patterns. This paper focuses on assessing the level of pollution in the Lake. Therefore, the physico-chemical and microbiological properties of water were investigated on 15 selected sampling on the representative sites of the Lake. Microbiological and physico-chemical analyses were performed in accordance with the European Standard Methods and World Health Organization (WHO). Multivariate statistical methods (Hierarchical Clustering Analysis: HCA, and Principal Component Analysis: PCA) were applied to figure out the influence of pollutants disposal in Qarraoun Lake. PCA was used to identify a reduced number of four principal components, which demonstrated $67.46 \%$ of both temporal and spatial changes. CA shows that the Lake is divided into four clusters, where the central represent the most favorable one. Pollution index was used to classify the level of pollution of different sites in the Lake.
\end{abstract}

Keywords: Contamination, river water, reservoir, Lebanon, clusters, pollution index 


\section{Introduction}

Water quality is considered the main factor controlling health and the state of disease in all aspects of life, including man, animals, and vegetation. However, surface water quality is often subjected to contamination since it is uncovered and is in direct touch with human. Pollution as a primary problematic surface water issue is largely controlled by natural processes (weathering and soil erosion) and anthropogenic inputs (municipal and industrial wastewater discharge). The anthropogenic discharges constitute a constant polluting source, whereas surface runoff is a seasonal phenomenon that is largely affected by climate within the basin (Singh et al., 2004; Vega et al., 1996).

The Litani River is the largest of its type in Lebanon with about 2180 $\mathrm{km}^{2}$ basin area and $178 \mathrm{~km}$ from a hydrologic point of view. The basin of the Litani River is divided into two hydrologic units, the Upper and Lower Basins, which are joined together at the Qarraoun Lake. This Lake is an artificial construction that was established in 1956 to harvest water for several purposes such as hydropower and irrigation.

The lake of Qarraoun is a typical example of surface water pollution in Lebanon. This is because it feeds more than 200,000 people downstream the Litani River. Recently, water supply has been extended to the neighboring upstream region. Hence, Water pollution in the Lake became a common visible criterion and it has been exaggerated in the last few decades as a result of population growth and the changing climatic conditions. Therefore, the physical, chemical, and biological properties have been strongly affected either directly or indirectly caused by human activity and their derivatives. This has been evidenced by several applied studies in Lebanon (Dia, 1993; IDRC, 2007; Shaban \& Nassif, 2007; Jurdi et al., 2010; Korfali et al., 2010; ELARAD/UNDP, 2011; Slim et al., 2011).

Lately, the Qarraoun Lake has been given attention by decision makers in Lebanon. This is because water from the Lake is oriented within a national project for water supply entitled as Project-800m. Here, all villages below $800 \mathrm{~m}$ will be provided water from the Lake. Nevertheless, great caution would be taken since the water in the Lake is polluted. Therefore, there is the need to determine the aspects of pollutions as well as their levels. Moreover, identifying sources of pollution is another need in order to apply appropriate future plans.

The present study aimed at evaluating the water quality of the Qarraoun Lake at 18 selected sites. The samples were collected in the month of September 2012, which was a typical timing between summer and winter. The resulting data set was manipulated using the PCA and $\mathrm{CA}$ multivariate techniques to evaluate information about the similarities. In addition, dissimilarities exist among the different sampling sites. However, this is used to 
identify water quality variables for spatial dissimilarity, as well as to ascertain the sources where contamination impact is derived from.

\section{Material and Methods}

Sample Collection and Analytical Procedures

Water samples from 18 sites (Figure 1 and Table 1) were collected at $0.5 \mathrm{~m}$ depth on September 2012 from the Qaraaoun Lake. The samples were kept in $2 \mathrm{~L}$ polyethylene plastic bottles which were previously cleaned with metal free soap, rinsed repeatedly with distilled water, soaked in $10 \%$ nitric acid for $24 \mathrm{~h}$, and finally rinsed with ultrapure water. All water samples were maintained at $4^{\circ} \mathrm{C}$ before they reached the laboratory, and then later for processing and analysis.

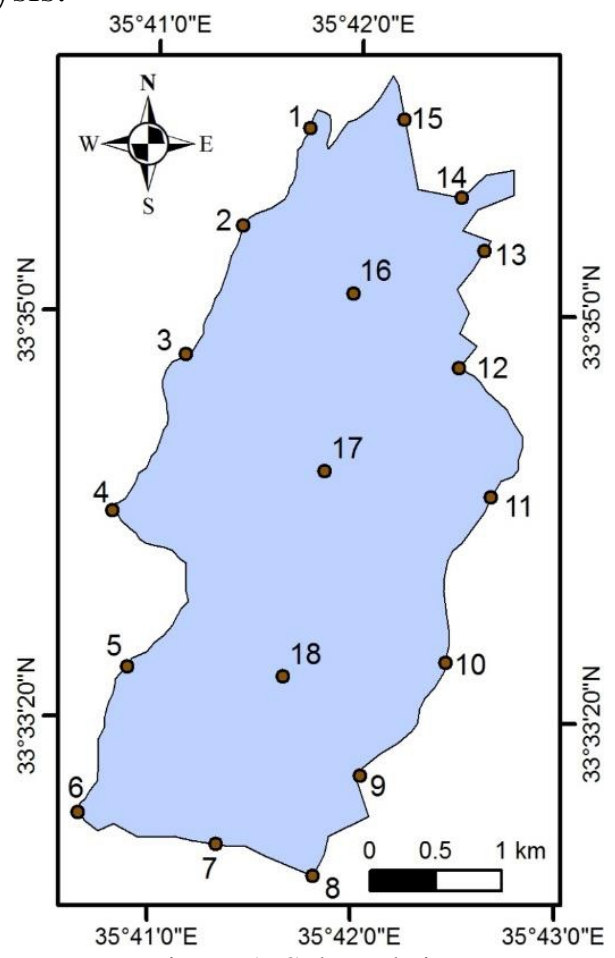

Figure 1. Selected sites 
Table 1. Sites of the collected sample from the Qarraoun Lake

\begin{tabular}{|c|c|c|c|}
\hline \multirow[t]{2}{*}{ Site No. } & \multicolumn{2}{|c|}{ Samples Lat/Long } & \multirow[t]{2}{*}{ Site Description } \\
\hline & Latitude & Longitude & \\
\hline 1 & $33^{\circ} 35^{\prime} 32^{\prime \prime}$ & $35^{\circ} 41^{\prime} 44^{\prime \prime}$ & $\begin{array}{c}\text { A littoral site between water and land, facing fruit } \\
\text { tree and vineyards }\end{array}$ \\
\hline 2 & $33^{\circ} 35^{\prime} 16^{\prime \prime}$ & $35^{\circ} 41^{\prime} 30^{\prime \prime}$ & Site facing fruit tree and wild open field \\
\hline 3 & $33^{\circ} 34^{\prime} 42^{\prime \prime}$ & $35^{\circ} 41^{\prime} 12^{\prime \prime}$ & Site facing sand dunes, fruit and olive tree \\
\hline 4 & $33^{\circ} 34^{\prime} 15^{\prime \prime}$ & $35^{\circ} 41^{\prime} 00^{\prime \prime}$ & $\begin{array}{c}\text { Site facing herbaceous vegetation, vineyards and } \\
\text { olive tree }\end{array}$ \\
\hline 5 & $33^{\circ} 33^{\prime} 35^{\prime \prime}$ & $35^{\circ} 41^{\prime} 01^{\prime \prime}$ & Site facing bare dune and fruit tree \\
\hline 6 & $3^{\circ} 33^{\prime} 01^{\prime \prime}$ & $35^{\circ} 41^{\prime} 02^{\prime \prime}$ & Near the equipment and industrial site \\
\hline 7 & $33^{\circ} 32^{\prime} 54^{\prime \prime}$ & $35^{\circ} 41^{\prime} 15^{\prime \prime}$ & In the middle of the dam \\
\hline 8 & $33^{\circ} 32^{\prime} 51^{\prime \prime}$ & $35^{\circ} 41^{\prime} 50^{\prime \prime}$ & Opposite to the forest and olives tree \\
\hline 9 & $33^{\circ} 32^{\prime} 59^{\prime \prime}$ & $35^{\circ} 41^{\prime} 52^{\prime \prime}$ & Opposite to the fruits and horticulture \\
\hline 10 & $33^{\circ} 33^{\prime} 2^{\prime \prime}$ & $35^{\circ} 42^{\prime} 17^{\prime \prime}$ & Opposite to the low urban activity \\
\hline 11 & $33^{\circ} 34^{\prime} 06^{\prime \prime}$ & $35^{\circ} 42^{\prime} 25^{\prime \prime}$ & $\begin{array}{l}\text { Site facing horticulture, fruits and few little } \\
\text { urban }\end{array}$ \\
\hline 12 & $33^{\circ} 34^{\prime} 47^{\prime \prime}$ & $35^{\circ} 42^{\prime} 34^{\prime \prime}$ & $\begin{array}{c}\text { Opposite to horticulture and herbaceous } \\
\text { vegetation }\end{array}$ \\
\hline 13 & $33^{\circ} 34^{\prime} 57^{\prime \prime}$ & $35^{\circ} 42^{\prime} 30^{\prime \prime}$ & Site facing Vineyards \\
\hline 14 & $33^{\circ} 35^{\prime} 25^{\prime \prime}$ & $35^{\circ} 42^{\prime} 44^{\prime \prime}$ & Opposite to herbaceous vegetation and fruits tree \\
\hline 15 & $33^{\circ} 35^{\prime} 43^{\prime \prime}$ & $35^{\circ} 42^{\prime} 11^{\prime \prime}$ & Site facing vineyards and Horticulture \\
\hline 16 & $33^{\circ} 35^{\prime} 09^{\prime \prime}$ & $35^{\circ} 41^{\prime} 59^{\prime \prime}$ & In the middle of the lake \\
\hline 17 & $33^{\circ} 34^{\prime} 07^{\prime \prime}$ & $35^{\circ} 41^{\prime} 45^{\prime \prime}$ & In the middle of the lake \\
\hline 18 & $33^{\circ} 33^{\prime} 49^{\prime \prime}$ & $35^{\circ} 41^{\prime} 41^{\prime \prime}$ & In the middle of the lake \\
\hline
\end{tabular}

Consequently, 21 variables were analyzed and reported in this study. As shown in Table 2, the measurements of water quality parameters are summarized on the basis of standard methods established for surface water monitoring in Lebanon. The temperature, $\mathrm{pH}$, electrical conductivity (EC), TDS, and DO of each water sample were measured in-situ using a mercury thermometer, digital $\mathrm{pH}, \mathrm{EC}$ and $\mathrm{DO}$, respectively. All water samples were analyzed for the physico-chemical parameters within 48 hours of collection. SO4 was determined spectrophotometrically by the Barium Sulfate Turbidity Method. In addition, NH4-N was measured with Nessler's reagent. NO3-N and NO2-N were analyzed by phenol disulfonic acid colorimetry and N-(1naphthyl)-ethylenediamine colorimetry, respectively. TN and TP were analyzed by absorption spectrophotometry after decomposition with potassium peroxodisulfate $\left(\mathrm{K}_{2} \mathrm{~S}_{2} \mathrm{O}_{8}\right)$.

The acid-treated water samples were analyzed for the determination of major cations ( $\mathrm{Ca}, \mathrm{Na}$, and $\mathrm{K}$ ) which were measured by flame photometry. $\mathrm{Mg}$ was determined by the Flame Atomic Absorption Spectrometer (FAAS). For trace and toxic elements, the volume of water samples was reduced by heating at $60^{\circ} \mathrm{C}$ on an electric hot plate. Thus, this was determined using Hydride Generation Atomic Absorption Spectrometer method (HGAAS). On the other 
hand, $\mathrm{Pb}$ was analyzed by using the Electrothermal Atomic Absorption Spectrometer (ETAAS), and $\mathrm{Cr}^{+\mathrm{IV}}$ by using the Dinitrodiphenyl Carbazide Spectrophotometric (DCS) method.

Table 2. Water quality parameters, their units and analytical methods used

\begin{tabular}{|c|c|c|c|}
\hline Parameters & Unit & Method & Analytical Methods \\
\hline $\mathrm{pH}$ & pH & pH & pH Meter Model HI 98103 \\
\hline Temperature & $\mathbf{T}$ & ${ }^{\circ} \mathbf{C}$ & Thermometer \\
\hline $\begin{array}{c}\text { Specific } \\
\text { Conductivity }\end{array}$ & Ec & $\mathbf{m S} / \mathbf{m}$ & Electrometric Hach Model $44600\left(0.1 \mu \mathrm{S} \mathrm{cm}^{-1}\right)$ \\
\hline $\begin{array}{c}\text { Total Dissolved } \\
\text { Solid }\end{array}$ & TDS & $\mathrm{mg} / \mathrm{L}$ & Electrometric Hach Model $44600\left(0.1 \mathrm{mg} \mathrm{L}^{-1}\right)$. \\
\hline Nitrate Nitrogen & $\begin{array}{c}\text { NO3- } \\
\mathbf{N}\end{array}$ & $\mathrm{mg} / \mathrm{L}$ & Spectrophotometer Method: EPA 352.1 \\
\hline Nitrite Nitrogen & $\begin{array}{c}\text { NO2- } \\
\mathbf{N}\end{array}$ & mg/L & Spectrophotometric method : EPA 354.1 \\
\hline $\begin{array}{c}\text { Ammoniacal } \\
\text { Nitrogen }\end{array}$ & $\begin{array}{c}\text { NH4- } \\
\text { N }\end{array}$ & $\mathbf{m g} / \mathbf{L}$ & Spectrophotometric \\
\hline Phosphates & PO4 & $\mathrm{mg} / \mathrm{l}$ & ISO 6878:2004 \\
\hline Sulphate & SO4 & $\mathrm{mg} / \mathrm{L}$ & Spectrophotometric: AOAC 973.57. \\
\hline Calcium & $\mathbf{C a}$ & $\mathrm{mg} / \mathrm{L}$ & Flame Photometer \\
\hline Magnesium & Mg & $\mathrm{mg} / \mathrm{L}$ & FAAS \\
\hline Chloride & $\mathbf{C l}$ & $\mathrm{mg} / \mathrm{L}$ & Titrimetric \\
\hline Potassium & $\mathbf{K}$ & $\mathrm{mg} / \mathrm{L}$ & Flame Photometer \\
\hline Sodium & $\mathbf{N a}$ & $\mathrm{mg} / \mathrm{L}$ & Flame Photometer \\
\hline Lead & $\mathbf{P b}$ & $\mathrm{mg} / \mathrm{l}$ & ETASS \\
\hline Metals Analysis & $\begin{array}{c}\text { Fe, } \\
\mathrm{Zn}, \\
\mathrm{Cu}, \\
\mathrm{Cr}, \\
\mathrm{Al}, \\
\mathrm{Ba}, \\
\mathrm{k}, \mathbf{N i}, \\
\mathrm{Mn}\end{array}$ & $\mathrm{mg} / \mathrm{l}$ & $\begin{array}{c}\text { Atomic Absorption Spectrophotometer } \\
\text { (AOAC 974.27). }\end{array}$ \\
\hline
\end{tabular}

In total coliform (TC) counts, and after the necessary dilution was carried out in the water samples, $10 \mathrm{~mL}$ of the sample was put into three tubes each with double strength. $1 \mathrm{~mm}$ was put into each of first three single- 
strength tubes, and $0.1 \mathrm{~mL}$ sample was put into each one of the other three tubes. Thus, all these samples contain Brilliant Green Lactose Bile Broth (BGLBB, Oxoid) medium. The tubes were incubated at $37{ }^{\circ} \mathrm{C}$ for 24 to $48 \mathrm{~h}$. During this period, the gas accumulation in Durham tubes was observed and The Most Probable Coliform Number index was determined using the MPN (Finstein, 1972; Collins \& Lyne, 1987; Veissman \& Hammer, 1993).

In the faecal coliform (FC) counts, the same process was followed as in the total coliform (TC) counts, but the tubes were incubated at $44.5{ }^{\circ} \mathrm{C}$. The Most Probable Faecal Coliform Number was determined from MPN index considering the gas accumulation in Durham tubes (Finstein, 1972; Collins \& Lyne, 1987; Veissman \& Hammer, 1993).

\section{Statistical Procedures}

Statistical parameters of physico-chemical and microbiological analyses data were used to present the values of water quality characteristics. Pearson's correlation coefficient (r) was used to show correlation between all parameters data using the SPSS Statistical Software 16.0 2007 (SPSS Inc.,). GIC are used to put the data in graph. Multivariate analysis of data set for the lake water quality was performed using Principal Component and Cluster Analysis techniques.

In this research, the calculations were performed based on the correlation matrix of chemical components. Also, the PCA were obtained from the standardized analytical data. CA was used to detect spatial similarity for grouping sampling sites located within the monitoring network.

\section{Results and Discussion}

Lebanon's water supply depends mainly on surface water sources with more than $60 \%$ of total available water. Lakes and ponds constitute a major portion of surface water. Thus, the largest artificial lake in Lebanon, the Qarraoun Lake, is considered as a fundamental water sources, especially for irrigation purposes. Even though the lake has been established since more than six decades, yet it is still utilized to compensate a large volume of water shortage in the Bekaa plain and a part of the coastal area as well.

Lately, the Qarraoun Lake is joined to a project at a national level. Thus, water from the lake will be conveyed to the areas below 800 meters. Nevertheless, water in the lake is being contaminated and this can be obviously observed. Therefore, conveying water to different regions will be harmful for human and crops. For this purpose, we were motivated towards applying this research. Thus, water from 18 different sites in the lake was sampled for detailed physiochemical and microbiological analysis. These parameters play a significant role in water quality, distribution, and the 
abundance of aquatic organisms in the water. Also, it can be used for determining the water quality and productivity of the lake (Kara, 2004).

Table 3. Physical parameters of water in the Qarraoun Lake

\begin{tabular}{|c|c|c|c|c|c|}
\hline \multirow{2}{*}{ Sites } & \multicolumn{5}{|c|}{ Parameters } \\
\cline { 2 - 6 } & $\mathrm{T}\left({ }^{\circ} \mathrm{C}\right)$ & $\mathrm{pH}$ & $\mathrm{EC}\left(\mu \mathrm{cm}^{-1}\right)$ & $\mathrm{TDS}(\mathrm{mg} / \mathrm{l})$ & $\mathrm{DO}$ \\
\hline 1 & $\mathbf{2 8 . 7}$ & $\mathbf{7 . 8 9}$ & $\mathbf{6 0 1}$ & $\mathbf{3 2 0}$ & $\mathbf{4 . 0 2}$ \\
\hline 2 & $\mathbf{2 8 . 2}$ & $\mathbf{7 . 8 6}$ & $\mathbf{6 1 8}$ & $\mathbf{3 3 3}$ & $\mathbf{4 . 1 2}$ \\
\hline 3 & $\mathbf{2 7 . 3}$ & $\mathbf{8 . 0 7}$ & $\mathbf{5 8 7}$ & $\mathbf{3 2 0}$ & $\mathbf{3 . 6 7}$ \\
\hline 4 & $\mathbf{2 7}$ & $\mathbf{7 . 8 4}$ & $\mathbf{5 0 1}$ & $\mathbf{3 4 8}$ & $\mathbf{3 . 4 3}$ \\
\hline 5 & $\mathbf{2 7 . 2}$ & $\mathbf{7 . 9 5}$ & $\mathbf{3 4 1}$ & $\mathbf{1 7 4}$ & $\mathbf{6 . 7 6}$ \\
\hline 6 & $\mathbf{2 5 . 4}$ & $\mathbf{8 . 0 4}$ & $\mathbf{3 5 9}$ & $\mathbf{2 3 0}$ & $\mathbf{6 . 9 7}$ \\
\hline 7 & $\mathbf{2 4 . 5}$ & $\mathbf{8 . 0 1}$ & $\mathbf{3 7 8}$ & $\mathbf{1 5 8}$ & $\mathbf{5 . 6 5}$ \\
\hline 8 & $\mathbf{2 5 . 3}$ & $\mathbf{7 . 9 5}$ & $\mathbf{6 0 8}$ & $\mathbf{3 8 6}$ & $\mathbf{5 . 0 2}$ \\
\hline 9 & $\mathbf{2 5 . 7}$ & $\mathbf{8 . 0 3}$ & $\mathbf{5 3 0}$ & $\mathbf{3 2 0}$ & $\mathbf{5 . 2 1}$ \\
\hline 10 & $\mathbf{2 6 . 6}$ & $\mathbf{7 . 6 5}$ & $\mathbf{6 1 2}$ & $\mathbf{4 0 5}$ & $\mathbf{4 . 0 3}$ \\
\hline 11 & $\mathbf{2 7 . 2}$ & $\mathbf{8}$ & $\mathbf{6 9 3}$ & $\mathbf{5 4 8}$ & $\mathbf{4 . 0 1}$ \\
\hline 12 & $\mathbf{2 7 . 9}$ & $\mathbf{7 , 6 5}$ & $\mathbf{6 8 9}$ & $\mathbf{5 1 1}$ & $\mathbf{2 . 9 7}$ \\
\hline 13 & $\mathbf{2 8 . 1}$ & $\mathbf{7 . 8 2}$ & $\mathbf{7 2 0}$ & $\mathbf{5 3 0}$ & $\mathbf{3 . 5 4}$ \\
\hline 14 & $\mathbf{2 8 . 2}$ & $\mathbf{7 . 8 1}$ & $\mathbf{8 1 0}$ & $\mathbf{5 8 9}$ & $\mathbf{2 . 0 1}$ \\
\hline 15 & $\mathbf{2 9 . 6}$ & $\mathbf{8 . 0 1}$ & $\mathbf{8 2 0}$ & $\mathbf{5 5 9}$ & $\mathbf{3 . 4 3}$ \\
\hline 16 & $\mathbf{2 8 . 9}$ & $\mathbf{7 . 9 5}$ & $\mathbf{3 8 6}$ & $\mathbf{1 5 6}$ & $\mathbf{9 . 0 5}$ \\
\hline 17 & $\mathbf{2 7 . 2}$ & $\mathbf{7 . 1 7}$ & $\mathbf{3 3 2}$ & $\mathbf{1 6 6}$ & $\mathbf{1 0 . 5}$ \\
\hline 18 & $\mathbf{2 5 . 4}$ & $\mathbf{7 . 3 4}$ & $\mathbf{3 5 4}$ & $\mathbf{1 7 2}$ & $\mathbf{1 2 . 4 5}$ \\
\hline WHO & $6.5-8.5$ & $15.57-21.10$ & Max 1500 & $<500 \mathrm{mg} / 1$ & $<10 \mathrm{mg} / 1$ \\
$(2006)$ & & & $\mu \mathrm{s} / \mathrm{cm}$ & & \\
\hline & & & & & \\
\hline
\end{tabular}

The temperature of the collected samples ranged from 24.6 to $28.7^{\circ} \mathrm{C}$. According to Lawson (2011), these values were within the acceptable levels for survival (fish). Thus, the $\mathrm{pH}$ values of collected water samples ranged from 7.17 to 8.07 , within the limit range of 6-9 allowed by the SEPAC for water quality.

In some sites, the alkaline (8.07) $\mathrm{pH}$ is a result of the presence of carbonates and bicarbonates in high concentration in Qarraoun Lake and this is due to the presence of Carbonate rocks. Thus, these results show that Qarraoun Lake is a favored environment for the living flora and fauna.

Dissolved Oxygen (DO) with a range between 2.01 and $12.45 \mathrm{mg} / \mathrm{l}$ is an important parameter of biogenic element, and it is also an important indicator of environmental health water (concentration of nutrients and organic matter). This level reflects the status of biological growth and water environmental pollution (WEI Qin-sheng, 2010). The DO concentration was depending on the changing of temperatures. The lower DO concentrations, the highest concentrations of decaying organic matter. In Qarraoun Lake, a clear decrease in DO (Table 3) levels was noticed in the sites 1-4 (at the effluent of the river in the Lake) as well as between the sites 10 and 14 
eastern part of the Lake. This can be attributed to a higher concentration of organic matter there. The higher concentration of DO in sites 4 and 5 for examples is due to the different kind of pesticides used for agricultural activities. The highest DO was found at sites 16-18 at the center of lake.

Electrical conductivity is a tool to assess the purity of water. EC and TDS were found in the range 332- $820 \mu \mathrm{S} / \mathrm{cm}$ and $156-589 \mathrm{ppm}$, respectively. According to $\mathrm{WHO}$, they are in acceptable levels.

\section{Microbial Contamination}

According to the microbial analysis, the results show that the range of Total Coliform (TC) is 4570 to $27500 \mathrm{col} / 100 \mathrm{ml}$. The Figure 2 shows that the northern part (sites 1-4) of lakes and the site 14 was more polluted. The less contaminated was the sites 15 to 18 (center).

The concentration of FC varies from $10 \mathrm{col} / 100 \mathrm{ml}$ in the middle of the lake to $761 \mathrm{col} / 100 \mathrm{ml}$ in the site 8 . The contamination is also high in the site 1, which is the point of contact between the Lake and the Litani River effluents. The sites 9, 11, 12 are moderately polluted by FC. The distribution and the level of contamination by fecal and total coliform in the sites are different. As a result, according to the data, the sites 2, 4, 5, 6, 7, 10, 13, 14, 15 are moderate to less polluted by FC and severe to highly contaminated by TC.

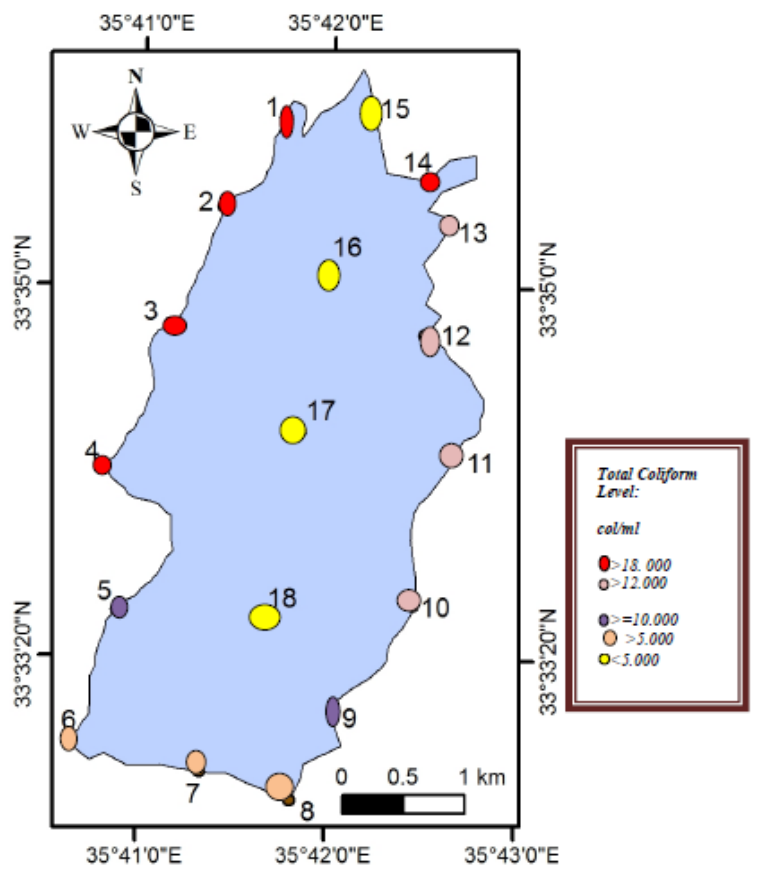

Figure 2. Distribution of Total Coliform in the Qarraoun Lake 
Table 4. The mean values of nutrient

\begin{tabular}{|c|c|c|c|c|c|}
\hline \multirow{2}{*}{$\begin{array}{c}\text { Parameter } \\
(\mathrm{ppm})\end{array}$} & \multicolumn{3}{|c|}{ Values } & \multirow{2}{*}{$\begin{array}{r}\text { WHO } \\
(2006)\end{array}$} & \multirow{2}{*}{$\begin{array}{l}\text { Libnor } \\
\text { ( } 99)\end{array}$} \\
\hline & Min & Mean & Max & & \\
\hline $\mathrm{NO}_{3}{ }^{+}$ & 0.87 & 4.93 & 9.95 & $\begin{array}{c}\text { Max 50 } \\
\text { ppm }\end{array}$ & 45 ppm \\
\hline $\mathrm{NO}_{2}^{+}$ & 0.01 & 0.95 & 1.89 & $\begin{array}{c}\text { Max } 0.2 \\
\text { ppm }\end{array}$ & 0.05 ppm \\
\hline $\mathrm{NH}^{+}{ }^{+}$ & 0.01 & 1.065 & 3.09 & $\begin{array}{c}\text { Max } 0.5 \\
\text { ppm }\end{array}$ & $1 \mathrm{ppm}$ \\
\hline $\mathrm{Cl}^{-}$ & 0.91 & 25.15 & 38.1 & $\begin{array}{c}\text { Max 250 } \\
\text { ppm }\end{array}$ & 200 ppm \\
\hline $\mathrm{PO}_{3}{ }^{4+}$ & 1.45 & 2.29 & 5.45 & Max 1 ppm & $1 \mathrm{ppm}$ \\
\hline $\mathrm{SO}_{4}^{2-}$ & 25.7 & 32.09056 & 36.29 & $\begin{array}{c}\text { Max 250 } \\
\text { ppm }\end{array}$ & $250 \mathrm{ppm}$ \\
\hline $\mathrm{Na}^{+}$ & 8.1 & 8.98 & 9.7 & $\begin{array}{c}\text { Max 150 } \\
\text { ppm }\end{array}$ & 150 ppm \\
\hline $\mathrm{Cd}$ & 0.7 & 1.79333 & 3.8 & 0.003 ppm & 0.005 ppm \\
\hline $\mathrm{Cu}^{2+}$ & 0.02 & 0.04 & 0.076 & 1 ppm & 1 ppm \\
\hline $\mathrm{Fe}^{3+}$ & 0.01 & 0.15 & 1.78 & $0.3 \mathrm{ppm}$ & $0.3 \mathrm{ppm}$ \\
\hline $\mathrm{Mg}^{2+}$ & $1-6$ & $2-9$ & $2-7$ & $50 \mathrm{ppm}$ & $50 \mathrm{ppm}$ \\
\hline $\mathrm{Br}$ & 10.5 & 26.32 & 39.98 & 0.01 ppm & Not available \\
\hline $\mathrm{Zn}$ & 0.0037 & 0.06 & 0.16 & 25 ppm & $5 \mathrm{ppm}$ \\
\hline $\mathrm{Cr}^{6+}$ & 0.005 & 0.03 & 0.07 & 0.05 ppm & $0.05 \mathrm{ppm}$ \\
\hline $\mathrm{Mn}$ & 0.002 & 0.02 & 0.09 & $0.05 \mathrm{ppm}$ & $0.05 \mathrm{ppm}$ \\
\hline
\end{tabular}

Table 4 shows that the mean values of nitrite, ammonium, and phosphorus were almost higher than the acceptable guidelines, while the concentration of nitrate, chloride, and sulfate were among the acceptable levels.

In order to describe the source of contaminants which are discharging in the reservoir, land cover, which is a land use component, must be identified. The map (Figure 3) covers the area that surrounded the Lake, and it includes mainly urban and industrial sites, bare soil, and vegetation cover. The map was extracted from Landsat ETM satellite image (30 $\mathrm{m}$ resolution) 
of the year 2012, by using ERDAS-Imagine software for image processing. Thus, a supervised classification was applied for this purpose.

Furthermore, there are several sources of pollution that surrounded the Qarraoun Lake. They mainly imply: agricultural residue, farms, and different forms of industries, sewage network outlets, and municipal solid waste dumping. In order to detect the source and the efficiency of contamination, a table of correlation (Table 5) between analytic values was plotted. For example, industrial discharges (e.g. mineral and tanning processing, etc) can explain the significant association between $\mathrm{Fe} / \mathrm{Cd}$ and $\mathrm{Cd} / \mathrm{Mn}$. Additionally, the association between Nitrate and fecal Coliform ( $\mathrm{r}$ $=0.585, \mathrm{p}<0.05)$ and Nitrate/Total Coliform $(\mathrm{r}=0.696, \mathrm{p}<0.05)$ are significant. Thus, this is due to the domestic wastewater effluents and sewage. Sodium/ chloride $(r=0.810 \mathrm{p}<0.05)$ association are significant and Ammonium/iron are due to fertilizers and other agricultural sources.

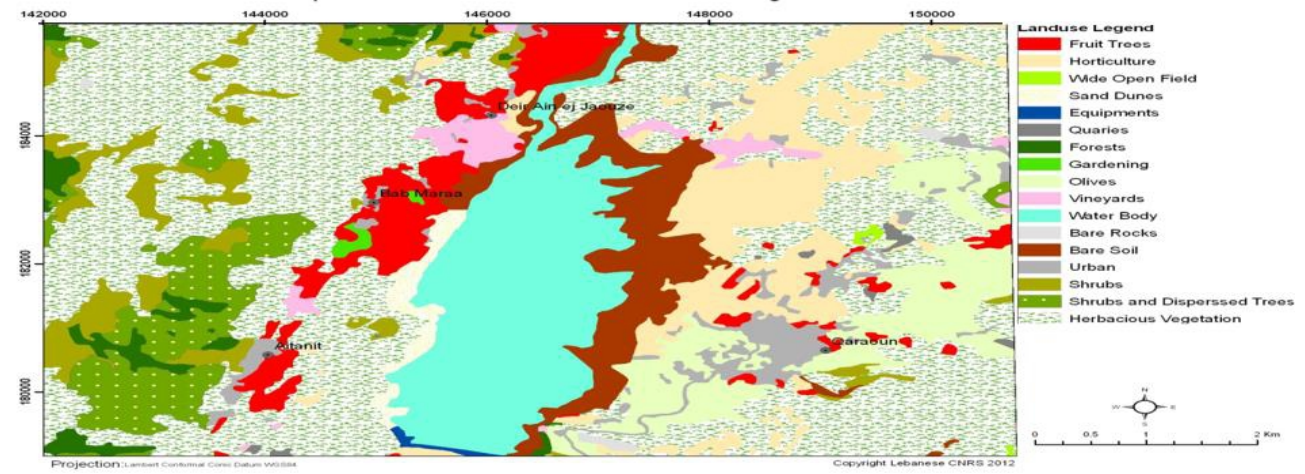

Figure 3. Land cover of Qarraoun (CNRS, 2012) 
Table 5. Matrix of correlation

\begin{tabular}{|c|c|c|c|c|c|c|c|c|c|c|c|c|c|c|c|c|c|c|c|}
\hline & $\mathrm{T}$ & $\mathrm{pH}$ & EC & TDS & DO & $\mathrm{NO} 3$ & $\mathrm{NO} 2$ & NH4 & $\mathrm{Cl}$ & $\mathrm{SO} 4$ & PO4 & $\mathrm{Br}$ & $\mathrm{Fe}$ & $\mathrm{Cd}$ & $\mathrm{Zn}$ & $\mathrm{Mn}$ & $\mathrm{Cu}$ & $\mathrm{Cr}$ & $\mathrm{Na}$ \\
\hline $\mathrm{T}$ & 1.00 & & & & & & & & & & & & & & & & & & \\
\hline $\mathrm{pH}$ & 0.04 & 1.00 & & & & & & & & & & & & & & & & & \\
\hline $\mathrm{EC}$ & 0.53 & 0.25 & 1.00 & & & & & & & & & & & & & & & & \\
\hline TDS & 0.44 & 0.19 & 0.96 & 1.00 & & & & & & & & & & & & & & & \\
\hline DO & -0.31 & -0.55 & -0.81 & -0.77 & 1.00 & & & & & & & & & & & & & & \\
\hline NO3 & 0.30 & 0.46 & 0.58 & 0.49 & -0.66 & 1.00 & & & & & & & & & & & & & \\
\hline NO2 & -0.04 & 0.52 & 0.04 & 0.12 & -0.36 & 0.11 & 1.00 & & & & & & & & & & & & \\
\hline NH4 & -0.20 & 0.38 & 0.01 & 0.01 & -0.27 & 0.28 & 0.38 & 1.00 & & & & & & & & & & & \\
\hline $\mathrm{Cl}$ & 0.49 & -0.37 & 0.63 & 0.59 & -0.22 & 0.11 & -0.34 & -0.23 & 1.00 & & & & & & & & & & \\
\hline SO4 & 0.38 & 0.06 & 0.24 & 0.19 & -0.30 & 0.39 & -0.16 & 0.04 & 0.04 & 1.00 & & & & & & & & & \\
\hline PO4 & 0.28 & -0.66 & -0.18 & -0.15 & 0.46 & -0.42 & -0.42 & -0.34 & 0.38 & 0.18 & 1.00 & & & & & & & & \\
\hline $\mathrm{Br}$ & -0.26 & 0.49 & -0.26 & -0.33 & 0.00 & 0.12 & 0.25 & 0.48 & -0.40 & 0.10 & -0.22 & 1.00 & & & & & & & \\
\hline $\mathrm{Fe}$ & 0.31 & 0.09 & 0.09 & -0.04 & -0.14 & 0.23 & -0.07 & 0.51 & 0.02 & 0.03 & 0.00 & 0.12 & 1.00 & & & & & & \\
\hline $\mathrm{Cd}$ & 0.59 & -0.22 & 0.37 & 0.27 & -0.26 & 0.07 & -0.03 & 0.19 & 0.46 & 0.15 & 0.15 & -0.34 & 0.57 & 1.00 & & & & & \\
\hline $\mathrm{Zn}$ & -0.05 & 0.13 & 0.38 & 0.39 & -0.50 & 0.30 & 0.01 & 0.23 & 0.18 & 0.03 & -0.48 & -0.18 & 0.16 & 0.24 & 1.00 & & & & \\
\hline $\mathrm{Mn}$ & -0.46 & 0.18 & -0.20 & -0.09 & 0.10 & 0.05 & 0.33 & 0.48 & -0.43 & -0.19 & -0.27 & 0.13 & -0.19 & -0.38 & -0.02 & 1.00 & & & \\
\hline $\mathrm{Cu}$ & -0.17 & 0.05 & 0.43 & 0.41 & -0.33 & 0.14 & -0.34 & -0.29 & 0.20 & -0.02 & -0.17 & -0.21 & -0.23 & -0.29 & 0.35 & 0.06 & 1.00 & & \\
\hline $\mathrm{Cr}$ & -0.55 & 0.11 & -0.49 & -0.49 & 0.36 & -0.16 & -0.08 & -0.28 & -0.48 & -0.35 & -0.18 & -0.07 & -0.33 & -0.62 & -0.27 & 0.26 & 0.11 & 1.00 & \\
\hline $\mathrm{Na}$ & 0.54 & -0.48 & 0.46 & 0.50 & -0.08 & 0.01 & -0.22 & -0.46 & 0.81 & 0.15 & 0.59 & -0.42 & -0.23 & 0.26 & -0.16 & -0.37 & 0.10 & -0.47 & 1.00 \\
\hline
\end{tabular}


In order to simplify the evaluation of water quality, however, PCA was applied for physical-chemical nutrient and its correlation with the bacteria.

PCA provides information on the most significant parameters used to describe the entire data set, data reduction, and to summarize the statistical correlation among constituents in the water with a minimum loss of original information (Helena et al., 2000). PCA has been used to determine the structure of the underlying dataset and to identify the unobservable, latent pollution sources.

Projection of the original variables on the sub space of the PCs are called loading, and it coincides with the correlation coefficients between PCs and variables (Vega et al., 1998). Loading of four retained PCs are presented in Table 6.

Table 6. The four principal components of physical-chemical parameters of the Qarraoun Lake

\begin{tabular}{|c|c|c|c|c|}
\hline Parameters & F1 & $\mathrm{F} 2$ & F3 & F4 \\
\hline $\mathrm{T}$ & 0.23 & -0.22 & 0.23 & 0.22 \\
\hline $\mathrm{pH}$ & 0.12 & 0.34 & -0.03 & 0.27 \\
\hline $\mathrm{EC}$ & $\begin{array}{l}0.38 \\
\end{array}$ & -0.06 & -0.16 & $\begin{array}{c}\mathbf{0 . 1 0} \\
\end{array}$ \\
\hline TDS & 0.35 & -0.06 & -0.19 & 0.13 \\
\hline DO & -0.36 & -0.14 & 0.09 & -0.14 \\
\hline $\mathrm{NO}_{3}$ & 0.29 & 0.16 & -0.03 & 0.08 \\
\hline $\mathrm{NO}_{2}$ & 0.05 & 0.26 & 0.10 & 0.23 \\
\hline $\mathrm{NH}_{4}$ & 0.09 & 0.30 & 0.30 & -0.16 \\
\hline $\mathrm{Cl}$ & 0.23 & -0.31 & -0.08 & -0.16 \\
\hline $\mathrm{SO}_{4}$ & 0.14 & -0.06 & 0.13 & 0.38 \\
\hline $\mathrm{PO}_{4}$ & -0.10 & -0.36 & 0.13 & -0.01 \\
\hline $\mathrm{Br}$ & -0.07 & 0.25 & 0.19 & 0.24 \\
\hline $\mathrm{Fe}$ & 0.12 & 0.05 & 0.43 & -0.23 \\
\hline $\mathrm{Cd}$ & 0.22 & -0.15 & 0.36 & -0.25 \\
\hline $\mathrm{Zn}$ & 0.21 & 0.11 & -0.10 & -0.25 \\
\hline $\mathrm{Mn}$ & -0.09 & 0.25 & -0.11 & -0.10 \\
\hline $\mathrm{Cu}$ & 0.10 & -0.02 & -0.48 & -0.03 \\
\hline $\mathrm{Cr}$ & -0.24 & 0.14 & -0.29 & -0.14 \\
\hline $\mathrm{Na}$ & 0.14 & -0.37 & -0.08 & 0.13 \\
\hline $\mathrm{TC}$ & 0.25 & 0.19 & 0.10 & -0.28 \\
\hline $\mathrm{FC}$ & 0.28 & 0.16 & -0.10 & -0.08 \\
\hline Eigenvalue & 5.91 & 4.63 & 2.57 & 1.71 \\
\hline Variability\% & 26.89 & 21.09 & 11.69 & 7.80 \\
\hline Cumulative \% & 26.89 & 47.98 & 59.66 & 67.46 \\
\hline
\end{tabular}

The four components of PCA analysis showed $67.46 \%$ (Table 6) of the variance data set as the eigenvectors. However, this classified the 21 physico-chemical parameters into four groups. The first component (F1) accounts for $26.89 \%$ of the total variance which was correlated with T, TDS, $\mathrm{Ec}, \mathrm{NO}_{3}, \mathrm{TC}, \mathrm{FC}, \mathrm{Zn}, \mathrm{Cd}, \mathrm{Cu}, \mathrm{Na}, \mathrm{SO}_{4}, \mathrm{Cl}^{-}$positives and with $\mathrm{DO}, \mathrm{Cr}$ negatives. 
The second component (F2) included $\mathrm{NO}_{2}, \mathrm{NH}_{4}, \mathrm{pH}, \mathrm{Mn}$, and $\mathrm{Br}$. This component is accounting for $21.09 \%$ of the total variance measured that demonstrated strong positive loadings for major ions.

The third components (F3) is accounting for $11.69 \%$ of total variance. It was correlated positively with $\mathrm{Fe}, \mathrm{Cd}, \mathrm{PO}_{4}$, and negatively with $\mathrm{Cu}$.

The fourth components (F4) included $\mathrm{SO} 4$, which demonstrated $7.80 \%$ of the total variance.

Subsequently, the analysis of the result shows that most of the variables highly contributed by F1, F2, and F3. The majority of information is explained by the first three factorial axes. As a result, we took it into consideration during this study.

\section{Cluster Analysis}

It is usually used and it is defined as the classification of similar objects into groups, where the number of groups as well as their forms are unknown (Kaufman et al., 1990). This is with the primary purpose being the assembly of objects based on the characteristics they possess. Hierarchical agglomerative clustering is the most common approach, which provides instinctive similarity relationships between any sample and the entire data set. Hence, it is typically illustrated by a dendrogram (tree diagram). The dendrogram presents a picture of the groups and their proximity to one another, with a dramatic reduction in the dimensionality of the original data (Alberto et al., 2001).

Hearchi Diect Cassfication

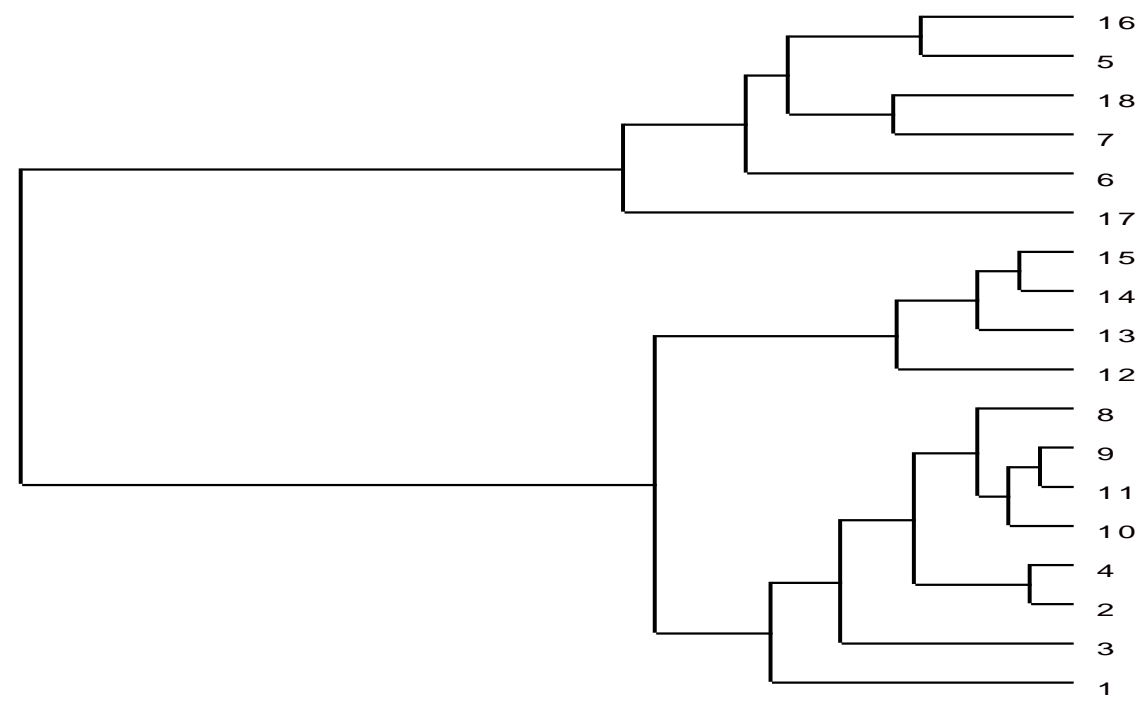

Figure 3. Agglomerative hierarchical clustering based on the PCA scores 
A dendrogram of sampling sites obtained by Ward's method is shown in Figure 3. It was divided into:

- Cluster 1 corresponded to sites 1, 3, 2, 4, 10, 11, 9, 8;

- Cluster 2 corresponded to sites $12,13,14,15$;

- Cluster 3 corresponded to the site 17; and

- Cluster 4 corresponded to sites 6, 7, 18, 5, 16.

Cluster analysis revealed that water quality measured at these sites appeared to be affected by different pollutant sources, and thus describes the different properties at each site with respect to chemical and microbial variables. Therefore, we apply the pollution index $\mathrm{P}$ method to demonstrate the results of CA analysis. The details of the comprehensive pollution index are shown below:

$$
\mathrm{P}=\frac{1}{n} \sum_{i=1}^{n} C i / S i
$$

Where $P$ is comprehensive pollution index, $C i$ is the measured concentration of the pollutant $(\mathrm{mg} / \mathrm{L}), S i$ represents the limits allowed by the WHO for water quality, and $n$ is the number of selected pollutants. Ultimately, the values determined for $P$ could be used to classify the water quality level of the Lake (Table 7).

\begin{tabular}{|c|c|}
\hline Comprehensive Pollution Index $(P)$ & Water Quality Level \\
\hline$\leq 0.20$ & Cleanness \\
\hline $0.21-0.40$ & Sub-cleanness \\
\hline $0.41-1.00$ & Slight pollution \\
\hline $1.01-2.0$ & Moderate pollution \\
\hline$\geq 2.01$ & Severe pollution \\
\hline
\end{tabular}

Table 7. Standard of surface water quality classification (Zhao et al., 2012)

The values of the comprehensive pollution index (Table 8) were 2.72, $1.08,1.25,1.35,1.09,1.13,1.37,1.59$, and 1.09 for the sites $1,3,2,4,10$, 11, 9 and 8, respectively. This demonstrates severe to moderate pollution index. In sites 1, 2, 3, the quality of water was determined to have been influenced by the direct discharge from the Litani River. Also, it was characterized by high concentration of metals nutrients and bacteria. Figure 4 show that site 1 was characterized by severe pollution index, while sites 2 and 3 were characterized by moderate pollution index. Also, sites 8 and 9 were subjected to many tourist attractions, in addition to the presence of industrial activities that are characterized by moderate pollution. Site 11 is characterized by the presence of fruits and olive tree. All these sites are characterized by the presence of high levels of bacteria, nitrite, ammonium, potassium, and manganese. Therefore, this is due to the excessive fertilizers and animal wastes from the neighborhood. 
Table 8. Single and comprehensive pollution index

\begin{tabular}{|c|c|c|c|c|c|c|c|c|c|c|c|}
\hline Sites & $\mathbf{P}$ & $\mathrm{P}$ & $\mathrm{P}$ & $\mathrm{P}$ & $\mathrm{P}$ & $\mathrm{P}$ & $\mathrm{P}$ & $\mathrm{P}$ & $\mathrm{P}$ & $\mathrm{P}$ & $\mathrm{P}$ \\
& NO3 & $\mathrm{NO} 2$ & $\mathrm{~N} 44$ & $\mathrm{C}$ & $\mathrm{SO}$ & $\mathrm{PO} 4$ & $\mathrm{Na}$ & $\mathrm{Fe}$ & $\mathrm{Mn}$ & $\mathrm{C}$ & \\
\hline Site 1 & $\mathbf{6 . 8 9}$ & $\mathbf{3 . 8}$ & $\mathbf{6 . 1 4}$ & $\mathbf{0 . 1 0}$ & $\mathbf{0 . 1 2}$ & $\mathbf{2 . 4}$ & $\mathbf{0 . 0 5}$ & $\mathbf{5 . 9 3}$ & $\mathbf{1 . 8}$ & $\mathbf{0 . 0 3}$ & $\mathbf{2 . 7 2}$ \\
\hline Site 2 & $\mathbf{0 . 1 1}$ & $\mathbf{5 . 3 5}$ & $\mathbf{3 . 3 4}$ & $\mathbf{0 . 1 0}$ & $\mathbf{0 . 1 4}$ & $\mathbf{1 . 5}$ & $\mathbf{0 . 0 5}$ & $\mathbf{0 . 6}$ & $\mathbf{1 . 3 4}$ & $\mathbf{0 . 0 2}$ & $\mathbf{1 . 2 5}$ \\
\hline Site 3 & $\mathbf{0 . 1 9 7}$ & $\mathbf{4 . 6 6}$ & $\mathbf{2 . 0 2}$ & $\mathbf{0 . 1 0}$ & $\mathbf{0 . 1 2}$ & $\mathbf{1 . 8 9}$ & $\mathbf{0 . 0 5}$ & $\mathbf{0 . 4}$ & $\mathbf{1 . 3 4}$ & $\mathbf{0 . 0 3}$ & $\mathbf{1 . 0 8}$ \\
\hline Site 4 & $\mathbf{0 . 0 8}$ & $\mathbf{4 . 9 1}$ & $\mathbf{3 . 6}$ & $\mathbf{0 . 1 1}$ & $\mathbf{0 . 1 3}$ & $\mathbf{2 . 0 0}$ & $\mathbf{0 . 0 6}$ & $\mathbf{0 . 2 3}$ & $\mathbf{2 . 3 4}$ & $\mathbf{0 . 0 3}$ & $\mathbf{1 . 3 5}$ \\
\hline Site 5 & $\mathbf{0 . 1 0}$ & $\mathbf{6 . 7 6}$ & $\mathbf{0 . 0 2}$ & $\mathbf{0 . 0 0}$ & $\mathbf{0 . 1 3}$ & $\mathbf{1 . 5 6}$ & $\mathbf{0 . 0 5}$ & $\mathbf{0 . 2}$ & $\mathbf{0 . 7 7}$ & $\mathbf{0 . 0 2}$ & $\mathbf{0 . 9 6}$ \\
\hline Site 6 & $\mathbf{0 . 0 9}$ & $\mathbf{9 . 4 5}$ & $\mathbf{6 . 1 8}$ & $\mathbf{0 . 0 0}$ & $\mathbf{0 . 1 2}$ & $\mathbf{1 . 4 5}$ & $\mathbf{0 . 0 5}$ & $\mathbf{0 . 0 3}$ & $\mathbf{1}$ & $\mathbf{0 . 0 3}$ & $\mathbf{1 . 8 4}$ \\
\hline Site 7 & $\mathbf{0 . 0 2}$ & $\mathbf{3 . 3 5}$ & $\mathbf{1 . 3 4}$ & $\mathbf{0 . 0 2}$ & $\mathbf{0 . 1 2}$ & $\mathbf{1 . 6 5}$ & $\mathbf{0 . 0 5}$ & $\mathbf{0 . 0 6}$ & $\mathbf{1 . 5 2}$ & $\mathbf{0 . 0 7}$ & $\mathbf{0 . 8 2}$ \\
\hline Site 8 & $\mathbf{0 . 1 0}$ & $\mathbf{5 . 6 2}$ & $\mathbf{1 . 7 4}$ & $\mathbf{0 . 1 0}$ & $\mathbf{0 . 1 2}$ & $\mathbf{1 . 7 4}$ & $\mathbf{0 . 0 5}$ & $\mathbf{0 . 0 3}$ & $\mathbf{1 . 2 9}$ & $\mathbf{0 . 0 5}$ & $\mathbf{1 . 0 9}$ \\
\hline Site 9 & $\mathbf{0 . 1 1}$ & $\mathbf{5 . 9 7}$ & $\mathbf{4 . 6 2}$ & $\mathbf{0 . 1 0}$ & $\mathbf{0 . 1 2}$ & $\mathbf{1 . 9 3}$ & $\mathbf{0 . 0 6}$ & $\mathbf{0 . 2 9}$ & $\mathbf{1 . 3}$ & $\mathbf{0 . 0 4}$ & $\mathbf{1 . 5 9}$ \\
\hline Site 10 & $\mathbf{0 . 1 5}$ & $\mathbf{3 . 3 5}$ & $\mathbf{2 . 6 8}$ & $\mathbf{0 . 1 0}$ & $\mathbf{0 . 1 3}$ & $\mathbf{2 . 0 1}$ & $\mathbf{0 . 0 6}$ & $\mathbf{0 . 4}$ & $\mathbf{2 . 4}$ & $\mathbf{0 . 0 6}$ & $\mathbf{1 . 1 3}$ \\
\hline Site 11 & $\mathbf{0 . 0 9}$ & $\mathbf{5 . 2 4}$ & $\mathbf{4 . 0 2}$ & $\mathbf{0 . 1 0}$ & $\mathbf{0 . 1 2}$ & $\mathbf{2 . 6 4}$ & $\mathbf{0 . 0 6}$ & $\mathbf{0 . 4}$ & $\mathbf{1 . 0 4}$ & $\mathbf{0 . 0 3}$ & $\mathbf{1 . 3 7}$ \\
\hline Site 12 & $\mathbf{0 . 0 4}$ & $\mathbf{9 . 3 5}$ & $\mathbf{1 . 5 2}$ & $\mathbf{0 . 1 5}$ & $\mathbf{0 . 1 1}$ & $\mathbf{2 . 6 5}$ & $\mathbf{0 . 0 6}$ & $\mathbf{0 . 1 6}$ & $\mathbf{1 . 2 2}$ & $\mathbf{0 . 0 4}$ & $\mathbf{1 . 5 3}$ \\
\hline Site 13 & $\mathbf{0 . 1 0}$ & $\mathbf{5 . 0 2}$ & $\mathbf{0 . 3}$ & $\mathbf{0 . 1 3}$ & $\mathbf{0 . 1 3}$ & $\mathbf{2 . 1}$ & $\mathbf{0 . 0 6}$ & $\mathbf{0 . 0 6}$ & $\mathbf{3 . 3 1}$ & $\mathbf{0 . 0 5}$ & $\mathbf{1 . 1 2}$ \\
\hline Site 14 & $\mathbf{0 . 1 6}$ & $\mathbf{4 . 8 4}$ & $\mathbf{0 . 4}$ & $\mathbf{0 . 1 2}$ & $\mathbf{0 . 1 3}$ & $\mathbf{2 . 3 1}$ & $\mathbf{0 . 0 6}$ & $\mathbf{0 . 0 3}$ & $\mathbf{0 . 8 6}$ & $\mathbf{0 . 0 6}$ & $\mathbf{0 . 9}$ \\
\hline Site 15 & $\mathbf{0 . 1 3}$ & $\mathbf{1 . 1 5}$ & $\mathbf{0 . 1 2}$ & $\mathbf{0 . 1 5}$ & $\mathbf{0 . 1 3}$ & $\mathbf{2 . 3 1}$ & $\mathbf{0 . 0 6}$ & $\mathbf{0 . 1}$ & $\mathbf{1 . 1 2}$ & $\mathbf{0 . 0 7}$ & $\mathbf{0 . 5 3}$ \\
\hline Site 16 & $\mathbf{0 . 0 3}$ & $\mathbf{6 . 4 5}$ & $\mathbf{0 . 1 4}$ & $\mathbf{0 . 0 9}$ & $\mathbf{0 . 1 2}$ & $\mathbf{3 . 4 2}$ & $\mathbf{0 . 0 6}$ & $\mathbf{0 . 3 3}$ & $\mathbf{0 . 0 7}$ & $\mathbf{0 . 0 2}$ & $\mathbf{1 . 0 7}$ \\
\hline Site 17 & $\mathbf{0 . 0 2}$ & $\mathbf{0 . 0 5}$ & $\mathbf{0 . 0 4}$ & $\mathbf{0 . 1 2}$ & $\mathbf{0 . 1 4}$ & $\mathbf{5 . 4 5}$ & $\mathbf{0 . 0 6}$ & $\mathbf{0 . 0 3}$ & $\mathbf{0 . 0 7}$ & $\mathbf{0 . 0 3}$ & $\mathbf{0 . 6 0}$ \\
\hline Site 18 & $\mathbf{0 . 0 1}$ & $\mathbf{0 . 3}$ & $\mathbf{0 . 1 2}$ & $\mathbf{0 . 1 2}$ & $\mathbf{0 . 1 0}$ & $\mathbf{2 . 3 5}$ & $\mathbf{0 . 0 6}$ & $\mathbf{0 . 0 6}$ & $\mathbf{1 . 1 2}$ & $\mathbf{0 . 0 4}$ & $\mathbf{0 . 4 3}$ \\
\hline
\end{tabular}

Cluster 2 corresponded to sites 12, 13, 14 and 15 and the comprehensive pollution indices of these sites are 1.53,1.12, 0.9 and 0.53 , respectively. This demonstrates slight to moderate pollution index. All these sites are characterized by the presence of nutrients such as phosphate, nitrite, and bacterial contamination. Also, these sites are adjacent to open areas, which are cultivated by fruits tree and important human activity.

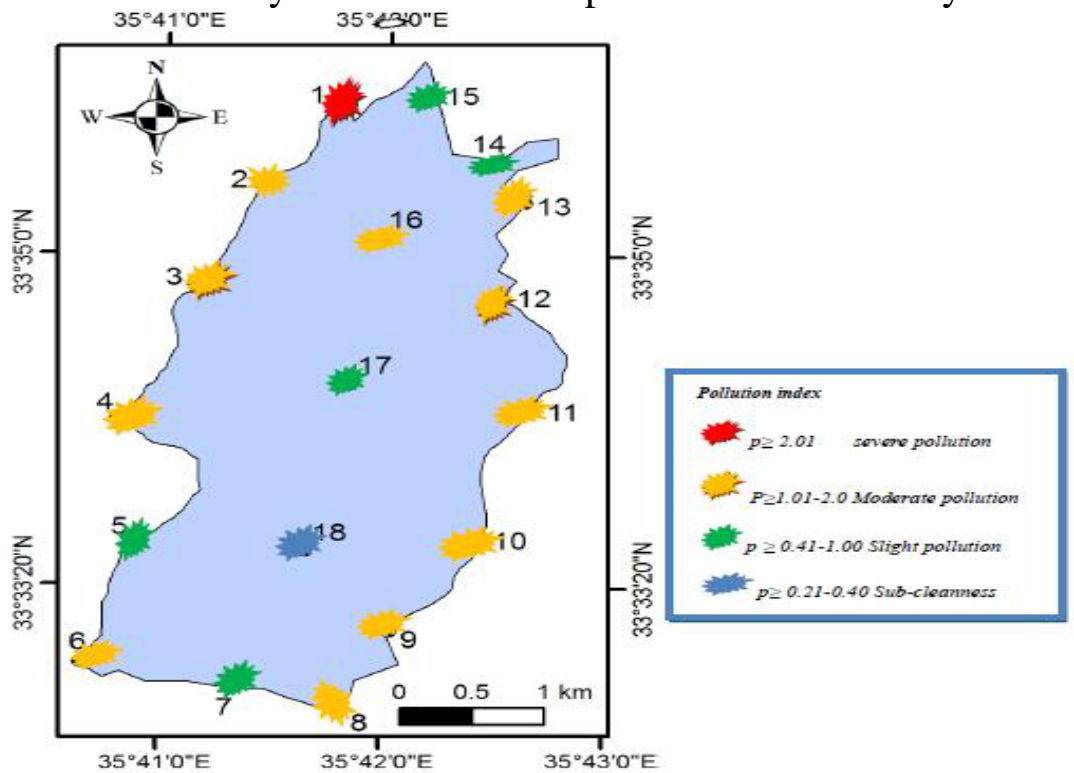

Figure 4. Level of pollution Index in investigated sites 
Cluster 3 corresponded to the site 17 was determined to be slightly polluted, with a comprehensive pollution index value of 0.60 . Whereas, cluster 4 corresponded to sites $6,7,18,5,16$ with 1.84, 0.82, 0.43, 0.96, 1.07 pollution indices. Sites 6 and 16 were characterized by moderate pollution influenced by the presence of nitrite and phosphate which may be due to the inputs of fertilizers because it seems that the site 16 was cultivated by fruits. Sites 5 and 7 were characterized by slight pollution and the Sub-cleanness site is the site 18 .

The spatial variation of water quality in the Qarraoun Lake showed that the water quality at the centre was better than all the sites surrounding the lake. Hence, it can be used for many purposes (irrigation, industrials activities).

\section{Conclusion}

Different multivariate statistical techniques were used to evaluate variations in water quality of the Qaraaoun Lake. PCA helped to identify the sources responsible for water quality variations in the Lake. The main reason for quality deterioration in the Lake is found to be attributed to the discharge from the Litani River, the residues of agricultural, in addition to irrigated lands that relies on fertilizers and industrial activities, the domestic sewage, and pollution from the surrounding villages to the Lake.

Clusters showed that the Lake is divided into three parts. In the first part, there is a receiving site which is characterized by the river inflow where evaporation rate is high; thus, severe pollution exists. The level of contamination by bacteria (TC and FC) was high. The pollution index was severe to moderate in this part because the lake has recently become a wastewater collector. In addition, human activities that exist near the lake exaggerate the problem, especially along the eastern shore where settlements are found. Pollution index of nitrite and phosphate was high in the western and the eastern part of this site.

The second part is characterized by slight to moderate pollution where the dam induces sediments deposition that may cause anaerobic beds.

The third part is characterized by the presence of slight pollution and the sub-cleanness parts. In this part, water can be used for irrigation, livestock, and fisheries and it can be used in industries after treatment.

The lake is completely polluted and about 80 of the sites were moderately polluted in the western and eastern part. As a result:

- To use their water in irrigation, the concentration of salts in water must be low. In this study, the concentration of $\mathrm{Cl}^{-}$and $\mathrm{Na}$ was very low (table). Additionally, the Bekaa plain soils do not yet suffer from a high salt content. For that, the reservoir water is fully suitable for irrigation use. 
- $\quad$ The presence of bacteria (TC and FC) eliminated the concept of using this water for drinking and in food and drink industries. Additionally, WHO guidelines (WHO, 1996) require that all water intended for drinking must be free from bacteria $(\mathrm{CF})$. However, filtration and disinfection treatment of water is necessary and preferable by ozone treatment based on the quality of odour and taste.

Study of sediment is necessary to the lake of Qarraoun.

\section{References:}

1. Alberto, WD., Del Pilar, DM., Valeria, AM., Fabiana, PS., Cecilia, HA., \& De Los Angeles, BM. (2001). Pattern recognition techniques for the evaluation of spatial and temporal variations in water quality. A case study: Suquia River basin (Cordoba-Argentina). WaterRes; 35: 2881-94.

2. Collins, CM. \& Lyne, PM. (1987). Microbiological Methods, Butter Worths \&Co. Ltd., London, p. 543.

3. Dia, A. (1993). Cycles des principaux paramètres physic-chimiques de deux Rivières Libanaises (Oronte et Yahfoûfa). Lebanese Science Bulletin, (6), 1, pp. 47-59.

4. ELARD/UNDP (2011). Business Plan for Combating Pollution of the Qaraoun Lake Final Business Plan References Prepared by 186.

5. Finstein, MS. (1972). Pollution Microbiology a Laboratory Manual, Marcel Dekker, New York, p. 273.

6. Helena, B., Pardo, R., Vega, M., Barrado, E., Fernandez, JM., \& Fernandez, L. (2000). Temporal evolution of groundwater composition in an alluvial aquifer (Pisuerga river, Spain) by principal component analysis. Water Res; 34: 807-16.

7. IDRC (2007). "Towards an Ecosystem Approach to the Sustainable management of the Litani Watershed- Lebanon". Litani River Authority, Lebanese National Council for Scientific Research, Development Studies association.

8. Jurdi, M., Korfali, S., El Rez, M., Karahagopian, N., \& Kriedyieh, K. (2010). Current Situation in the Litani River Basin: Water Quality Issues. Vision For Managing Water Resources in the Litani Basin, LRA, USAID, Lebanon.

9. Kara, Y.I.K. \& Basaran, D. (2004). Investigation of some physical and chemical parameters of water in the lake Isykli in Denizli, Turkey. Int. J. Agri. Boil., 6: 275-277.

10. Kaufman, L. \& Rousseeuw, PJ. (1990). Finding groups in data: an introduction to cluster analysis. New York: Wiley.

11. Korfali, S. I. \& Jurdi, M. S. (2010). Speciation of metals in bed sediments and water of Qaraaoun Reservoir, Lebanon. Environmental 
Monitoring and Assessment. Retrieved November 4, 2010. from http://www.ncbi.nlm.nih.gov/pubmed/20865319.

12. Lawson, E.O. (2011). Physico-chemical parameters and heavy metal contents of water from the Mangrove Swamps of Lagos Lagoon, Lagos, Nigeria. Advances in Biological Research, 5: 8-21.

13. SEPAC (State Environmental Protection Administration of China) (2002). Environmental quality standard for surface water, China (GB3838-2002). Beijing: China Environmental Science Press; (in Chinese).

14. Shaban, A. \& Nassif, N. (2007). Pollution in Qaraaoun Lake, Central Lebanon. Journal of Environmental Hydrology, 15, 1-14.

15. Slim, K. (1996). Contribution a l'étude de la flore algologique du bassin du litani. Leb. Sci. Res. Reports1 : 65-73.

16. Singh, KP., Malik, A., Mohan, D., \& Sinha, S. (2004). Multivariate statistical techniques for the evaluation of spatial and temporal variations in water quality of Gomti River (India)-a case study. Water Res, 38: 3980-92.

17. Slim, K., Atoui, A., El Zein, G., \& Temsah, M. (2011). Etude de l'impact du changement Climatique sur la qualité de l'eau et la prolifération toxique des cyanobactéries du Lac karaoun ( Liban) Larhyss. $10: 29-43$.

18. U.S. Environmental Protection Agency. Drinking Water and Health: What You Need to Know! (1999). U.S. Environmental Protection Agency, Office of Water. <www.epa.gov/safewater/ dwhealth.html>. Accessed March 21, 2001.

19. Veissman, W. \& Hammer, MJ. (1993). Water Supply and Pollution Control, Fifth Ed., Harper Collins College Publishers, New York, p. 860.

20. WEI Qin-sheng, WEI Xiu-hua, XIE Lin-ping, et al. (2010). Features of Dissolved Oxygen Distribution and Its Effective Factors in the Southern Yellow Sea in Spring, 2007. ADVANCES IN MARINE SCIENC, 28(2):179-185.

21. WHO (2006). Guidelines for Drinking-Water Quality, third ed. WHO, Geneva,Switzerland.

22. Zhao, Y., Xia, X.H., Yang, Z.F., \& Wang, F. (2011). Assessment of water quality in Baiyangdian Lake using multivariate statistical techniques. Procedia Environmental Sciences 8, 1240-1253. 